\title{
Comparative Analysis on the Haematological Parameters and Antioxidant Levels of Parboiled and Un-Parboiled Dichlorvos (DDVP)-Treated Beans
}

\author{
Nwuke Chinedu*, Nwauzobilom Darlington \\ Michael Okpara University of Agriculture, Umudike, Nigeria \\ Email: ${ }^{\star C h i n e d u \_n w u k e @ y a h o o . c o . u k ~}$
}

How to cite this paper: Chinedu, N. and Darlington, N. (2019) Comparative Analysis on the Haematological Parameters and Antioxidant Levels of Parboiled and UnParboiled Dichlorvos (DDVP)-Treated Beans. Journal of Biosciences and Medicines, 7 , 65-75.

https://doi.org/10.4236/jbm.2019.711006

Received: August 25, 2019

Accepted: November 4, 2019

Published: November 7, 2019

Copyright $\odot 2019$ by author(s) and Scientific Research Publishing Inc. This work is licensed under the Creative Commons Attribution International License (CC BY 4.0).

http://creativecommons.org/licenses/by/4.0/

(c) (i) Open Access

\begin{abstract}
This study comparatively evaluates the haematological and antioxidant effects of differently prepared (parboiled and un-parboiled) beans treated with sniper (i.e. a dichlorvos insecticide) and fed to wistar albino rats. Thirty (30) male wistar albino rats of known body weight were assigned into six (6) groups of 5 each. The groups received: $70 \mathrm{~g}$ and $30 \mathrm{~g}$ of un-parboiled beans (groups $1 \& 2$ ), $70 \mathrm{~g}$ and $30 \mathrm{~g}$ (groups $3 \& 4$ ) of parboiled beans compounded in the pellets as feed stock, beans only and standard feed for a period of 30 days. The rats were euthanized, and blood samples were collected after the termination of the study. Dichlorvos significantly decreased $(\mathrm{P}<0.05)$ the concentration of the antioxidant enzymes (GSH, GPx, SOD, CAT) in the groups fed with un-parboiled beans unlike the groups fed with parboiled beans which were non-significantly decreased. There was significant increase in the malondialdehyde concentration of the groups fed with un-parboiled beans. Dose dependent variations were seen in the packed cell volume (PCV), white blood cell (WBC), haemoglobin $(\mathrm{Hb})$ and platelet. But a reduced concentration of red blood cell count (RBC) for the un-parboiled groups and an increase in the parboiled group were seen, although both were not significant $(\mathrm{P}<0.05)$.
\end{abstract}

\section{Keywords}

Dichlorvos, Vigna unguiculata, Reactive Oxygen Species, Antioxidant Enzymes

\section{Introduction}

Pesticide, a damage control input to safeguard from insects and other pests, is 
considered to improve nutrition in food, and its use is assumed an economic, labor-saving, and efficient tool for pest management [1]. They are poisons; they are produced because they are toxic to one pest or the other [2]. Pesticides are an important management tool in agricultural enterprise; they increase yields and increase protection against insects at post-harvest and storage, and it has continued to be the bedrock of agriculture in modern times because of its unquantifiable benefits one of which include enhancement of shelf life of stored agricultural products [3]. Furthermore, pesticide is believed to improve competitive advantage in agriculture [4]. This is because pesticide use is deemed essential for retaining current production and yield levels, as well as maintaining a high-quality standard of life [4]. Organic phosphate is the most widely used pesticide worldwide and their metabolites are wide spread across different populations [5].

In Nigeria, cowpea is known by names such as, "akidi" in Igbo language, "wake" in Hausa language and "ewa" in Yoruba language. It makes a major part of Nigerian food. Vigna unguiculata is an important crop which plays a significant role in the diets of Nigerians serving as a major source of protein in the absence of sufficient animal protein for the population. It is rich in the amino acid lysine and tryptophan, as compared to cereal grains. Cowpeas are consumed either alone, or in combination with cereals to enhance the protein value. It could be cooked, made into soup or milled mixed with pepper, onions, groundnut oil, fried and taken as akara or it is wrapped with leaves and taken as "moin-moin" [6]; [7] but in all these methods of preparation, some people parboil beans while others do not parboil which is also dependent on the type of food they want to make from beans.

Dichlorvos or 2,2-dichlorovinyl dimethyl phosphate (commonly abbreviated as an DDVP) is an organophosphate, widely used as an insecticide to control household pests, in public health, and protecting stored product from insects [8]. It is used for the protection of greenhouse plants, fruits and vegetables against mushroom flies, aphids, spiders, mites, caterpillars and white flies. In Nigeria, DDVP is widely used by farmers for agricultural pest control [9]. The routes of exposure to DDVP include ingestion, inhalation and dermal exposure [10]. It is known that organophosphorus compounds, including DDVP, elicit neurotoxicity in mammals by inhibiting acetylcholinesterase activity [11]. Significant contamination of dried beans has been reported in Nigeria [9]. Beans are among the most versatile and commonly eaten foods throughout the world, and many varieties are grown in the US. Because of their nutritional composition, these economical foods have the potential to improve the diet quality and long-term health of those who consume beans regularly [12].

Oxidative stress has been identified as an important molecular mechanism of toxicity of DDVP [13]. It is defined as an imbalance between the production of free radicals and the antioxidant system of the body [14]. Enzymatic and nonenzymatic antioxidants scavenge free radicals and reactive oxygen species (ROS) in biological systems [15]. 
Several studies have been conducted to evaluate the effect of dichlorvos insecticide on blood and purpose of this study is to comparatively determine whether various preparations of contaminated beans could protect male Wistar rats from the adverse effects of sub-acute dichlorvos toxicity. Also evaluate the toxicity of DDVP with common local beans preparation on oxidative stress which has been identified as one of the important molecular mechanisms of DDVP toxicity. DDVP toxicity should be explored because the residues of DDVP have been detected in food stuffs in several countries including Nigeria [16].

\section{Materials and Method}

\subsection{Feed Formulation}

1) Beans preparation

Beans were bought in Ultra-modern market, Ubani, Umuahia, Abia State, Nigeria. dichlorvos based-pesticide, Sniper, was mixed with beans to achieve 1 $\mathrm{ml} / \mathrm{kg}$ and air dried for one (1) week. The contaminated beans were washed and prepared (cooked) separately where one group was parboiled for five (5 mins) minutes, the water was removed and a fresh water was added and cooked without the addition of any spices while the other group was completely cooked without parboiling.

2) Feed formation

The parboiled and un-parboiled beans were sundried and grounded into flour, mixed with standard feed stock at different ratios for the study. The samples were all pelletized for easy consumption by the rats.

\subsection{Chemicals}

Commercial grade dichlorvos (DDVP, 100\% solution containing $100 \mathrm{~g}$ per liter of 2,3-dichlorovinyldimethylphosphate) marketed as Sniper ${ }^{\circledR}$ was purchased from an agrochemical company in Umuahia, Nigeria. DDVP was reconstituted in soya oil (SO, Grand Cereals and Oil Mills Limited, Jos, Nigeria) to a 5\% stock solution.

\subsection{Experimental Animals}

The male Wistar rats used for this study were obtained from Department of Zoology and Environmental Biology (ZEB), University of Nigeria, Nsukka Enugu State were used for this study. The animals were transported in aluminum cages to Michael Okpara University of Agriculture Umudike, Abia State, Nigeria where the research was carried out. All animals were housed at controlled room temperature of about $27^{\circ} \mathrm{C}-30^{\circ} \mathrm{C}$ with a photoperiod of 12 -hour light and 12-hour dark per day. The animals were acclimatized fed Vital Growers Mash and water ad libitum and allowed to acclimatize to their environment for 14 days before experimentation on $1^{\text {st }}$ November, 2018. The research was approved by the University of Abuja research ethics committee and the animals were handled in accordance with the guidelines of the National Institute of Health Guide for 
Care and Use of Laboratory animals. The rats were handled in accordance with the international principles on the care and use of experimental animals and guidelines of Department of Physiology, Pharmacology, Biochemistry and Animal Health ethics committee-VPP/EC/2016/008 approved on 3 March 2016.

\subsection{Toxicological Study Design}

The Wistar rats were weighed and divided randomly into six groups, with 5 rats in each group. Thirty (30) male albino rats of the Wistar strain aged $10-12$ weeks and weighing $80-100 \mathrm{~g}$ bred were grouped as follows:

- Group $1=$ high conc ddvp in parboiled beans + feed (i.e. $70 \mathrm{~g}: 30 \mathrm{~g}$ ) + water.

- Group 2 = low conc of ddvp in parboiled beans + feed (i.e. $30 \mathrm{~g}: 70 \mathrm{~g}$ ) + water.

- Group 3 = high conc of ddvp in unparboiled beans + feed (i.e. $70 \mathrm{~g}: 30 \mathrm{~g}$ ) + water.

- Group 4 = low conc. of ddvp in unparboiled beans + feed (i.e. $30 \mathrm{~g}: 70 \mathrm{~g})+$ water.

- Group 5 = Beans only (Negative control).

- Group 6 = Feed + water only (Positive control).

At the end of the experimental weeks, the animals were euthanized and blood samples collected through cardiac puncture using $2 \mathrm{ml}$ syringes. Blood samples for hematological parameters were collected in EDTA-containing sample bottles and used for the tests.

\subsection{Determination of MDA Concentration}

The concentration of malondialdehyde (MDA) was evaluated in the serum. The method described by Wallin et al. (1993) [17] was used. The principle of the method was based on the spectrophotometric measurement of the colour developed during the reaction of thiobarbituric acid with MDA. The solutions were cooled under tap water and the absorbance was measured with an ultraviolet (UV) spectrophotometer ( $\mathrm{T} 80^{+} \mathrm{UV} / \mathrm{Visible}$ Spectrophotometer, PG Instruments Ltd., Leicestershire, United Kingdom) at $532 \mathrm{~nm}$. The concentration of MDA in the samples was calculated by using the absorbance coefficient, MDA-TBA complex $1.56 \times 10^{5} \mathrm{~cm}^{-1} \cdot \mathrm{M}^{-1}$.

\subsection{Assays of the Activities of Serum Antioxidant Enzymes}

Superoxide dismutase activity was assayed by the method of Arthur and Boyne [18] as contained in Randox kit. Catalase activity was assayed with the randox kit according to the method described by Sinha [19]. Glutathione peroxidase (GPx) was measured according to the method of Paglia and Valentine [20], while the reduced glutathione level was determined by the method of Exner et al. (2000) [21].

\subsection{Hematological Evaluations}

The total white blood cell count was determined by haemocytometry following 
the method described by Ochei and Kolhatkar [22]. The method of Ochei and Kolhatkar (2008) [22] was used for the determination of red blood cells, where, the blood specimen was diluted 1:200 with RBC diluting fluid and cells were counted under high power $(40 \times)$ objective by using a counting chamber. The number of cells was calculated and reported as the number of red cells $/ \mathrm{mm}^{3}$ of whole blood. The packed cell volume was determined using the microhaematocrit centrifuge (JouanA13 model).The haemoglobin $(\mathrm{Hb})$ concentration was measured spectrophotometrically by cyanomethaemoglobin method. The platelet count was obtained using the haemocytometer.

\subsection{Data Analysis and Statistical Procedures}

Statistical analysis of the data was carried out with SPSS version 22.0 using One Way Analysis of Variance (ANOVA). The statistically analyzed data were reported as Mean \pm SD. Significant difference was accepted at $95 \%$ confidence level of probability i.e. if $P<0.05$.

\section{Results}

\subsection{Effects of Consumption on Haematological Parameters}

The result of the effect of the pesticide on haematological indices is presented in Table 1 below. The WBC result showed non-significant increase for groups 1 and group 3 i.e. groups with high concentration of DDVP and a non-significant decrease for groups 2 and group 4 i.e. groups with low concentration of DDVP. The result showed a dose dependent significant decrease in the values of platelets when compared to the positive control, a significant decrease in group 1 (high conc of dichlorvos in un-parboiled beans) packed cell volume (PCV) while others showed a non-significant decrease. A significant decrease of hemoglobin for group 1 and group 3 and non-significant decrease was seen for groups 2 \& 4 when compared to the control. Decreased values of red blood cell count (RBC) for the parboiled groups and an increase in the un-parboiled group, although both were not significant $(\mathrm{P}<0.05)$.

Table 1. Haematological parameters.

\begin{tabular}{cccccc}
\hline Groups & WBC & PLATELET & PCV & Hb & RBC \\
\hline Group 1 & $6933.33 \pm 133.33^{\mathrm{a}}$ & $98.33 \pm 1.67^{\mathrm{a}}$ & $37.66 \pm 0.88^{\mathrm{b}}$ & $12.63 \pm 0.20^{\mathrm{a}}$ & $110.00 \pm 5.77^{\mathrm{a}}$ \\
Group 2 & $6333.33 \pm 176.38^{\mathrm{a}}$ & $100.00 \pm 5.77^{\mathrm{a}}$ & $43.00 \pm 0.57^{\mathrm{cd}}$ & $14.63 \pm 038^{\mathrm{bc}}$ & $110.00 \pm 5.77^{\mathrm{a}}$ \\
Group 3 & $6733.33 \pm 371.18^{\mathrm{a}}$ & $96.66 \pm 6.67^{\mathrm{a}}$ & $43.00 \pm 1.53^{\mathrm{cd}}$ & $13.96 \pm 38^{\mathrm{bc}}$ & $95.00 \pm 2.89^{\mathrm{a}}$ \\
Group 4 & $6533.33 \pm 133.33^{\mathrm{a}}$ & $110.00 \pm 5.77^{\mathrm{a}}$ & $44.66 \pm 1.33^{\mathrm{d}}$ & $14.86 \pm 0.43^{\mathrm{c}}$ & $96.67 \pm 8.82^{\mathrm{a}}$ \\
Group 5 & $6266.66 \pm 240.37^{\mathrm{a}}$ & $105.00 \pm 7.63^{\mathrm{a}}$ & $40.00 \pm 1.15^{\mathrm{bc}}$ & $13.63 \pm 0.20^{\mathrm{b}}$ & $106.67 \pm 6.67^{\mathrm{a}}$ \\
Group 6 & $6600.00 \pm 115.47^{\mathrm{a}}$ & $128.33 \pm 4.41^{\mathrm{b}}$ & $45.66 \pm 1.45^{\mathrm{d}}$ & $14.96 \pm 0.20^{\mathrm{c}}$ & $105.00 \pm 2.89^{\mathrm{a}}$ \\
\hline
\end{tabular}

\footnotetext{
${ }^{\text {abcd }}$ Groups with different superscript are significantly $(\mathrm{P}<0.05)$ different when compared along the column.
} 


\subsection{Effects of Consumption on Antioxidant Balance}

The glutathione (GSH) significantly decreased in the un-parboiled groups (i.e. group 3 and group 4) but non-significantly decreased in the parboiled groups (group 1 and group 2) when compared to the control as shown in Figure 1, catalase (CAT) activity decreased significantly in the un-parboiled groups (i.e. group 3 and group 4) but non-significantly decreased in the parboiled groups (group 1 and group 2) when compared to the control (Figure 2). The glutathione peroxidase (GPx) significantly decreased in the un-parboiled groups (i.e. group 3 and group 4) but non-significantly decreased in the parboiled groups (group 1 and group 2) when compared to the control as seen in Figure 3. The superoxide dismutase (SOD) showed a significant decrease in group 1, group 3 and group 4 but a non-significant decrease in group 2 when compared the positive control, group 6 as seen in Figure 4. The malondealdehyde (MDA) levels increased non-significantly in group 1 and group 2 i.e. the parboiled groups but significantly increased for group 3 and group 4 when compared to the positive control as shown in Figure 5.

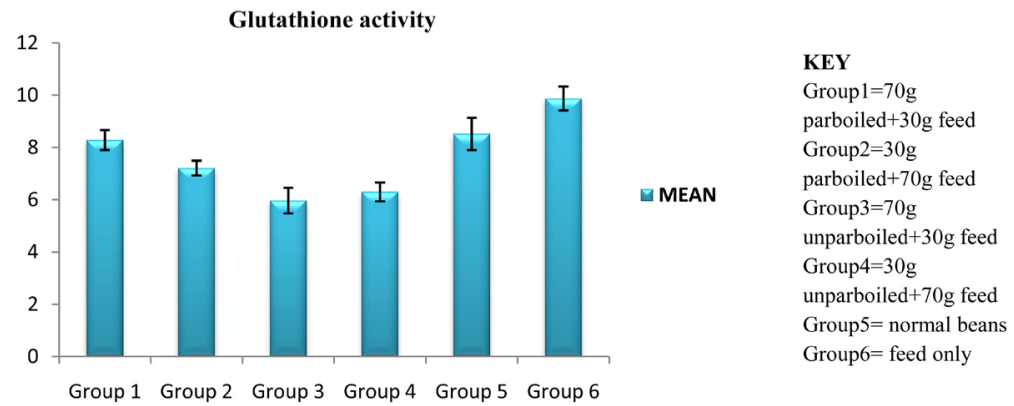

Figure 1. Serum glutathione activity in Wistar rats of different groups. From the chart above, there is significant $(\mathrm{P}<0.05)$ increase when group $6(9.87 \pm 0.46)$ is compared to group $3(5.97 \pm 0.49)$ and group $4(6.3 \pm 0.36)$ but a non-significant $(\mathrm{P}<0.05)$ increase is seen when group 6 is compared to group $1(8.28 \pm 0.38)$, group $2(7.21 \pm 0.28)$ and group $5(8.52 \pm 0.62)$.

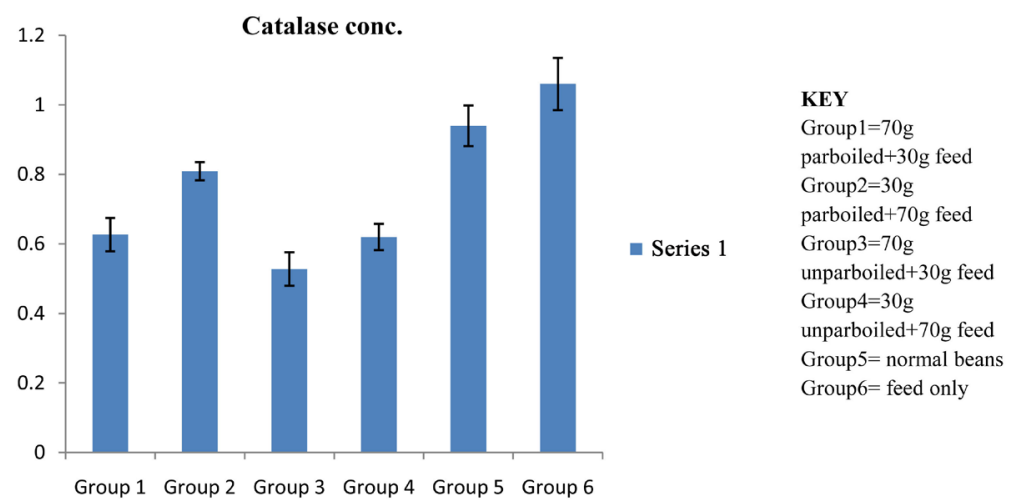

Figure 2. Serum catalase activity in Wistar rats of different groups. Figure shows a significant $(\mathrm{P}>0.05)$ increase when group $6(1.06 \pm 0.08)$ is compared to group $1(0.63 \pm 0.05)$, group $3(0.53 \pm 0.05)$ and group $4(0.62 \pm 0.04)$ but shows a non-significant increase when compared to group $2(0.81 \pm 0.03)$ and group $5(0.94 \pm 0.58)$. 


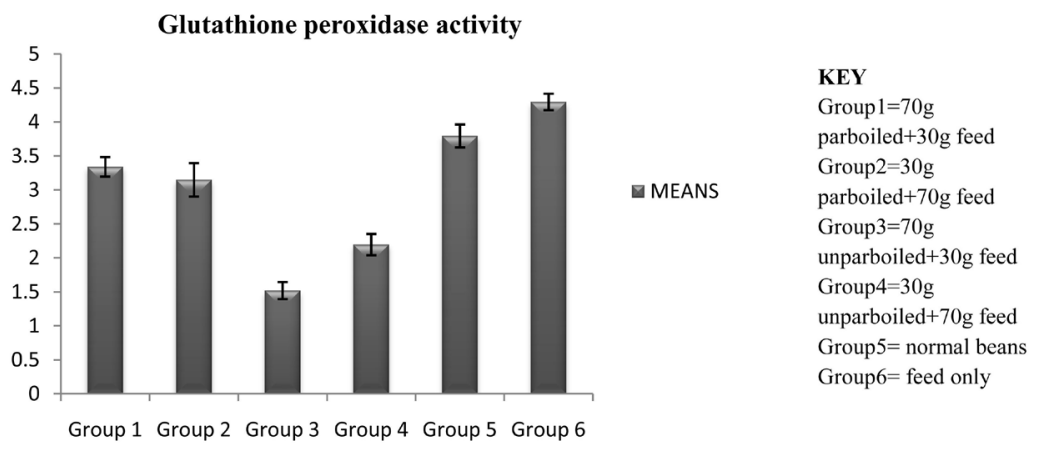

Figure 3. Serum glutathione peroxidase activity in wistar rats of different groups. From the Figure, the comparisons of group $6(4.30 \pm 0.12)$ to group $5(3.80 \pm 0.17)$, group 2 $(3.15 \pm 0.25)$ and group $1(3.34 \pm 0.14)$ show a non-significant $(\mathrm{P}<0.05)$ decrease but when group 6 is compared to group $3(1.52 \pm 0.12)$ and group $4(2.20 \pm 0.16)$, it shows a significant $(\mathrm{P}<0.05)$ decrease.

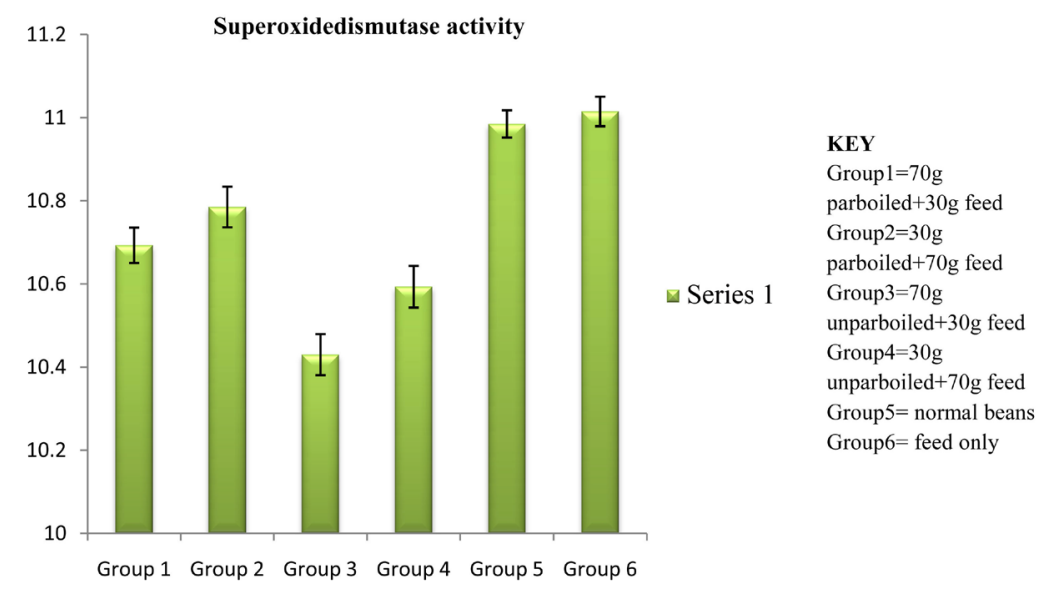

Figure 4. Effect of dichlorvos on serum superoxidedismutase activity in Wistar rats. From the chart above, the comparison of group $6(11.02 \pm 0.04)$ to group $1(10.69 \pm 0.04)$, group $3(10.43 \pm 0.05)$ and group $4(10.59 \pm 0.05)$ shows a significant $(\mathrm{P}<0.05)$ increase but shows a non-significant $(\mathrm{P}<0.05)$ increase when compared to group $2(10.79 \pm 0.05)$ and group $5(10.99 \pm 0.03)$.

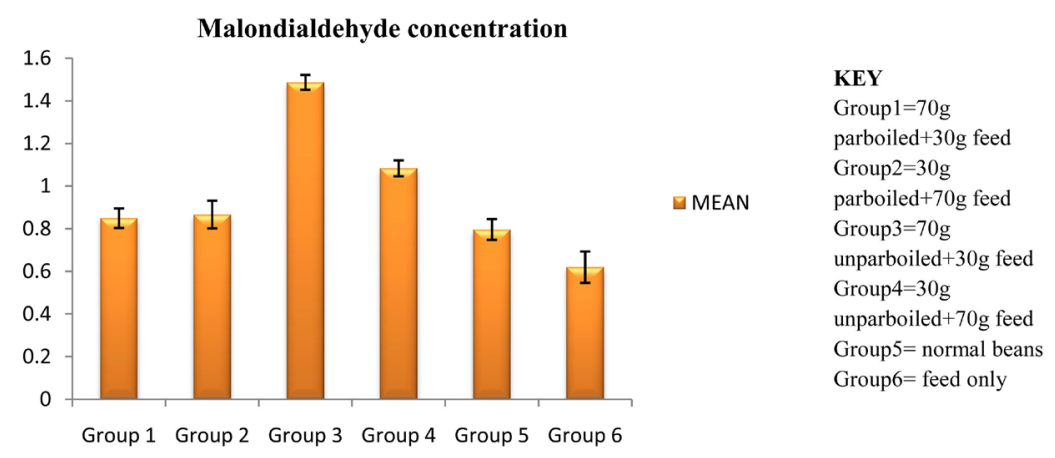

Figure 5. Effect of dichlorvos on serum totalmalondialdehyde concentrationin Wistar rats. From the chart above, there is non-significant $(\mathrm{P}<0.05)$ decrease in concentration of malondialdehyde when group $6(0.62 \pm 0.07)$ is compared to group $1(0.85 \pm 0.05)$, group $2(0.87 \pm 0.06)$ and group $5(0.80 \pm 0.05)$. But a significant decrease $(\mathrm{P}<0.05)$ is seen when group 6 is compared to group $3(1.49 \pm 0.03)$ and group $4(1.08 \pm 0.04)$. 


\section{Discussion}

Research on exposure [23], [24] and administration [25] of dichlorvos has shown that reactive oxygen species (ROS) are generated by dichlorvos thereby inducing oxidative stress. Prakasam [26] and Hsu [27] reported that excessive free radical production resulting in oxidative stress could be an important mechanism of organophosphate toxicity. From this study, glutathione which is usually the first line of defense against oxidative stress is significantly decreased when the treatment groups are compared to the control which is an indication that there is an increase in the levels of ROS generated in the cell [28] thereby leading to increased oxidative stress. It has been shown that certain environmental toxicants can elicit oxidative stress by converting the parent compound to its reactive metabolites [29]. Reduction in the GSH level may be due to indirect conjugation with excess electrophiles produced due to dichlorvos [13]. There is a significant decrease in the level of catalase (CAT) and glutathione peroxidase (GPx). The present result contradicts the reports of Kanu [24], Dwivedi [30] and [31] were the antioxidant enzymes were reported to have increased. However, this present report is supported by Ojo [32] \& Sharma [13].

There was a slight increase in the Malondealdehyde (MDA) levels which is a biomarker for lipid peroxidation (LPO) although the increase was not significant in all the groups except group 3 which showed a significant increase. Pesticides are known to move from treated agricultural areas into the broader environment, and then they can reach to the non-target organisms [33] implying that its usage may lead to undesirable residues as trace contaminants of food, the environment and living tissues hence, non-significant decrease $(\mathrm{P}<0.05)$ in group 4 suggests that the toxicity of dichlorvos may be dose-dependent and the parboiling of the beans may further reduce the concentration of pesticide residues deposited on the beans since the uncontaminated beans i.e. group 5 showed a significant increase when compared to the control.

The hematological parameters showed a dose dependent result which could have resulted from the levels of reactive oxygen species generated in the blood. In the report of the research carried out by Akomas [34], it was observed that there was the development of hypochronicanaemia due to a fall in the iron content of the body resulting from oxidative stress. Exposure to dichlorvos induces oxidative stress by generation of reactive oxygen species [23]. Oxidative stress occurs when the production of harmful molecules called free radicals is beyond the protective capability of the antioxidant defenses [35]. Disruption of the activities of antioxidants suggests alteration of the oxidative state of blood cells by the pesticide [24]. Therefore, this present study suggests that the consumption of dichlorvos can disrupt the antioxidant and pro-oxidant balance.

\section{Conclusions}

In summary, owing to this research work, dichlorvos has been seen to possess some level of toxicity when the dosage is not considered since it can induce oxi- 
dative stress by generating reactive oxygen species. Despite its relevance in agriculture (Pre-harvest and pro-harvest) in preserving stored products, when applied, a fraction of dichlorvos reaches to target pest while the rest enters into the food chain and leads to toxicity of different organs of the body and can be lethal overtime.

Unlike the parboiled groups, un-parboiled groups showed a significant decrease in the levels of the antioxidant enzymes which suggests the need of thorough washing and parboiling of beans during its preparation before consumption. Also, there is need to sparingly air-dry our beans in order to allow some of the chemicals used in its preservation to diffuse out completely since the comparison of group 5 (normal beans), negative control showed no significant difference in the antioxidant levels when compared to group 6.

The haematological parameters showed dose-dependent differences where groups with higher concentrations of dichlorvos varied from the control. Hence, there should be appropriate restriction and monitoring of the usage of dichlorvos based pesticides to ensure the right dosage meted out since dichlorvos is electrophilic in nature. Also, there should be an appropriate consideration before the application of dichlorvos preservative since some people parboil their beans while others do not parboil theirs although this research elucidates the need to parboil beans during its preparation.

\section{Conflicts of Interest}

The authors declare no conflicts of interest regarding the publication of this paper.

\section{References}

[1] Damalas, C.A. and Eleftherohorinos, I.G. (2011) Pesticide Exposure, Safety Issues, and Risk Assessment Indicators. International Journal of Environmental Research and Public Health, 8, 1402-1419. https://doi.org/10.3390/ijerph8051402

[2] Banjo, A. D., Aina, S. A., and Rije, O. I. (2010) Farmers' Knowledge and Perception towards Herbicides and Pesticides Usage in Fadama Area of Okun-Owa, Ogun State of Nigeria. African Journal of Basic and Applied Science, 2, 188-194.

[3] Olabode, O.S., Adeshina, G.O. and Olapeju, T.R. (2011) A Survey of Agricultural Chemicals Available to Farmers in South Western Nigeria. International Journal of Agricultural Economic and Rural Development, 4, 12.

[4] Delcour, I., Spanoghe, P. and Uyttendaele, M. (2015) Literature Review: Impact of Climate Change on Pesticide Use. Food Research International, 68, 7-15. https://doi.org/10.1016/j.foodres.2014.09.030

[5] Aprea, C., Strambi, M., Novelli, M.T., Lunghini, L. and Bozz, N. (2000) Biologic Monitoring of Exposure to Organophosphorus Pesticides in 195 Italian Children. Environmental Health Perspectives, 108, 521-525. https://doi.org/10.1289/ehp.00108521

[6] Oyenuga, V.A. (1968) Nigeria's Foods and Feeding Stuffs, Their Chemistry and Nutritive Value. 3rd Edition, Ibadan University Press, Ibadan, 99.

[7] Hung, Y.C., Mc Watters, K.H., Phillips, R.D. and Chinnan, M.S. (1990) Effects of 
Predecortications Drying Treatment on the Microstructure of Cowpea Products. Journal of Food Science, 55, 774-807. https://doi.org/10.1111/j.1365-2621.1990.tb05227.x

[8] Das, S. (2013) A Review of Dichlorvos Toxicity in Fish. Current World Environment, 8, 143-149. https://doi.org/10.12944/CWE.8.1.08

[9] Musa, U., Hati, S.S., Mustapha, A. and Magaji, G. (2010) Dichlorvos Concentrations in Locally Formulated Pesticide (Ota-piapia) Utilized in Northeastern Nigeria. Scientific Research and Essay, 5, 49-54.

[10] Koutros, S., Mahajan, R., Zheng, T., Hoppin, J.A., Ma, X., Lynch, C.F., Blair, A. and Alavanja, M.C. (2008) Dichlorvos Exposure and Human Cancer Risk: Results from the Agricultural Health Study. Cancer Causes \& Control, 19, 59-65. https://doi.org/10.1007/s10552-007-9070-0

[11] Hazarika, A., Sarkar, S.N., Hajare, S., Kataria, M. and Malik, J.K. (2003) Influence of Malathion Pretreatment on the Toxicity of Anilofos in Male Rats: A Biochemical Interaction Study. Toxicology, 185, 1-8. https://doi.org/10.1016/S0300-483X(02)00574-7

[12] Mitchell, D.C., Lawrence, F.R., Hartman, T.J. and Curran, J.M. (2009) Consumption of Dry Beans, Peas, and Lentils Could Improve Diet Quality in the US Population. Journal of the American Dietetic Association, 109, 909-913. https://doi.org/10.1016/j.jada.2009.02.029

[13] Sharma, P. and Singh, R. (2012) Dichlorvos and Lindane Induced Oxidative Stress in Rat Brain: Protective Effects of Ginger. Pharmacognosy Research, 4, 27-32. https://doi.org/10.4103/0974-8490.91031

[14] Verma, R.S., Mehta, A. and Srivastava, N. (2009) Comparative Studies on Chlorpyrifos and Methyl Parathion Induced Oxidative Stress in Different Parts of Rat Brain: Attenuation by Antioxidant Vitamins. Pesticide Biochemistry and Physiology, 95, 152-158. https://doi.org/10.1016/j.pestbp.2009.08.004

[15] Gultekin, F., Delibas, N., Yasar, S. and Kilinc, I. (2001) In Vivo Changes in Antioxidant Systems and Protective Role of Melatonin and a Combination of Vitamin C and Vitamin E on Oxidative Damage in Erythrocytes Induced by ChlorpyrifosEthyl in Rats. Archives of Toxicology, 75, 88-96. https://doi.org/10.1007/s002040100219

[16] Obida, M.G., Hati, S.S., Dimari, G.A. and Ogugbuaja, V.O. (2012) Pesticide Residues in Bean Samples from Northeastern Nigeria. ARPN Journal of Science and Technology, 2, 79-84.

[17] Wallin, B., Rosengren, B., Shertzer, H.G. and Camejo, G. (1993) Lipoprotein Oxidation and Measurement of Thiobarbituric Acid Reacting Substances Formation in a Single Microtiter Plate: Its Use for Evaluation of Antioxidants. Analytical Biochemistry, 208, 10-15. https://doi.org/10.1006/abio.1993.1002

[18] Arthur, J.R. and Boyne, R. (1985) Superoxide Dismutase and Glutathione Peroxidase Activities in Neutrophils from Selenium Deficient and Copper Deficient Cattle. Life Sciences, 36, 1569-1575. https://doi.org/10.1016/0024-3205(85)90381-9

[19] Sinha, A.K. (1972) Colorimetric Assay of Catalase. Analytical Biochemistry, 47, 389-394. https://doi.org/10.1016/0003-2697(72)90132-7

[20] Paglia, D.E. and Valentine, W.N. (1967) Studies on the Quantitative and Qualitative Characterization of Erythrocyte Glutathione Peroxidase. Journal of Laboratory and Clinical Medicine, 70, 158-169.

[21] Exner, R., Wessner, B., Manhart, N. and Roth, E. (2000) Therapeutic Potential of Glutathione. Wiener klinische Wochenschrift, 112, 610-616. 
[22] Ochei, J. and Kolhatkar, A. (2008) Medical Laboratory Science, Theory and Practices. Tata McGraw-Hill, 311-347.

[23] Wani, W.Y., Gudup, S., Sunkaria, A., Bal, A., Singh, P.P., Kandimalla, R.J., Sharma, D.R. and Gill, K.D. (2011) Protective Efficacy of Mitochondrial Targeted Antioxidant Mitochondria against Dichlorvos Induced Oxidative Stress and Cell Death in Rat Brain. Neuropharmacology, 61, 1193-1201. https://doi.org/10.1016/j.neuropharm.2011.07.008

[24] Kanu, K.C., Ijioma, S. and Atiata, O. (2016) Haematological, Biochemical and Antioxidant Changes in Wistar Rats Exposed to Dichlorvos Based Insecticide Formulation Used in Southeast Nigeria. Toxics, 4, 28. https://doi.org/10.3390/toxics4040028

[25] Oral, B., Guney, M., Demirin, H., Ozguner, M., Giray, S.G., Take, G., Mungan, T. and Altuntas, I. (2006) Endometrial Damage and Apoptosis in Rats Induced by Dichlorvos and Ameliorating Effect of Antioxidant Vitamins E and C. Reproductive Toxicology, 22, 783-790. https://doi.org/10.1016/j.reprotox.2006.08.003

[26] Prakasam, A., Sethupathy, S. and Lalitha, S. (2001) Plasma and RBCs Antioxidant Status in Occupational Male Pesticide Sprayers. Clinica Chimica Acta, 310, 107-112. https://doi.org/10.1016/S0009-8981(01)00487-9

[27] Hsu, D.Z., Hsu, C.H., Huang, B.M. and Liu, M.Y. (2001) Abamectin Effects on Aspartate Aminotransferase and Nitric Oxide in Rats. Toxicology, 165, 189-193. https://doi.org/10.1016/S0300-483X(01)00434-6

[28] Poljsak, B. and Jamik, P. (2010) Methodology for Oxidative State Detection in Biological Systems. In: Kozyrev, D. and Slutsky, V., Eds., Handbook of Free Radicals. Formation, Types and Effects, Cell Biology Research Progress Series, Nova Science, New York.

[29] de Lamirande, E., Jiang, H., Zini, A., Kodama, H. and Gagnon, C. (1997) Reactive Oxygen Species and Sperm Physiology. Reviews of Reproduction, 2, 48-54.

[30] Dwivedi, N. and Flora, S.J. (2015) Sub-Chronic Exposure to Arsenic and Dichlorvos on Erythrocyte Antioxidant Defense Systems and Lipid Peroxidation in Rats. Journal of Environmental Biology, 36, 383-391.

[31] Edem, V.F., Kosoko, A., Akinyoola, S.B., Owoeye, O., Rahamon, S.K. and Arinola, O.G. (2012) Plasma Antioxidant Enzymes, Lipid Peroxidation and Hydrogen Peroxide in Wistar Rats Exposed to Dichlorvos Insecticide. Archives of Applied Science Research, 4, 1778-1781.

[32] Ojo, A.O., Oyinloye, B.E., Ajiboye, B.O., Ojo, A.B., Akintayo, C.O. and Okezie, B. (2014) Dichlorvos Induced Nephrotoxicity in Rat Kidney: Protective Effects of Alstonia Boonei Stem Bark Extract. International Journal of Pharmacognosy, 1, 429-437.

[33] Tiryaki, O. and Temur, C. (2010) The Fate of Pesticide in the Environment. Journal of Biodiversity and Environmental Sciences, 4, 29-38.

[34] Akomas, S.C., Okafor, A.I. and Ijioma, S.N. (2014) Glucose Level, Haematological Parameters and Lipid Profile in Ficus. sur Treated Diabetic Rats. Comprehensive Journal of Agricultural and Biological Science, 2, 5-11.

[35] Alia, M., Horcajo, C., Bravo, L. and Goya, L. (2003) Effect of Grape Antioxidant Dietary Fiber on the Total Antioxidant Capacity and the Activity of Liver Antioxidant Enzymes in Rats. Nutr. Res, 23, 1251-1267.

https://doi.org/10.1016/S0271-5317(03)00131-3 